\title{
The moderating effect of Moral Values on the relationship between Authentic Leadership and Organizational Citizenship Behavior in the Police
} Force

\author{
Mohamed Abdelkarim Murad Mohamed \\ University of Dubai \\ Email: read-read-read@hotmail.com \\ Kamarul Zaman Bin Ahmad \\ University of Dubai \\ E-mail: kbinahmad@ud.ac.ae
}

\begin{abstract}
One of the key issues currently faced by the UAE Police Force is effective leadership. Authentic Leadership is one of the more contemporary theories of leadership and is linked with organizational citizenship behavior (OCB), which is the discretionary behaviors that are not directly stated in the job description. This research also incorporates the theory of person-environment fit, by proposing to examine whether a police employee with high moral values, fits with an authentic leader and a work environment where justice is paramount.
\end{abstract}

Keywords: Authentic Leadership, Justice, Person-environment fit, moral values, OCB

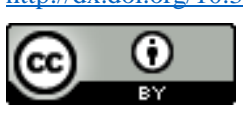

2523-6547 - Copyright: (C) 2017 The Authors. This is an open access article distributed under the terms of the Creative Commons Attribution License, which permits unrestricted use, distribution, and reproduction in any medium, provided the original author and source are credited. 


\section{INTRODUCTION}

One of the key issues currently faced by the UAE Police Force is meeting the vision of the government in 2021 regarding effective leadership. The National Agenda is that UAE should be one of the safest places in the world (The UAE National Agenda [UNA], 2010). One way this can be attained is through authentic leadership of its superiors. Authentic leadership comprises of self-awareness, moral perspective, balance processing and transparency. It is theorised that that will lead to positive outcomes for the subordinates such as job satisfaction, productivity, and organizational citizenship behavior (OCB). Gardner et al., 2005; Luthan and Avolio, 2003). OCB is defined as the discretionarybehaviors that are not expressly mentioned in the job description, but that adds value to the organization. OCB is often linked with increased productivity and is thus important to achieve the UAE National Agenda.

The backbone of this research is the person-environment fit theory which simply states that when people fit into their work environment, they will achieve positive outcomes like high job satisfaction, performance, and OCB.There is already abundant research about the positive relationships between authentic leadership and organizational justice with high job satisfaction, performance and OCB. However, the main research question addresses the gap in the literature which is: Is the subordinates' moral values a moderator of such relationships? In other words, will a person with high moral values fitwell with a leader who is highly authentic and a work environment where justice is prevalent? Put in another way, will a person with high moral values not fit with a leader who is perceived to be less authentic and an environment where justice is lacking? These are the research questions that this research aims to answer, and in doing so, hopefully, addresses the gap in the current literature. This research also touches on the equity theory in so far as organizational justice is concerned. Equity theory, according to Adam (1965) states that people experience cognitive dissonance when things are opposite of what they visualize as ideal. This theory also proposes that people are always comparing what they receive about what they contribute and that they often compare this with others. It would be particularly interesting to see whether the police forceand organization often associated with enforcing justice, is perceived to be fairby its employees when it comes to HR practices.Finally, this research also relies on Social Exchange Theory (Homans, 1958) relationships providing more benefits than costs will yield mutual trust and attraction (Blau, 1964).

\section{LITERATURE REVIEW}

\section{Authentic Leadership}

Luthans and Avolio (2003) defined authentic leadership "As a process that draws from both positive psychological capacities and a highly developed organizational context, which results in both greater self-awareness and selfregulated positive behaviors on the part of leaders and associates, fostering positive self-development" (Walumbwa et al., 2008, p. 89).Authentic leaders behave according to their beliefs, values, ethics, and morals when building relationships with their followers (Avolio \& Gardner, 2005; Walumbwa et al., 2008). It is sometimes described a behaving by one's true self (Walumbwa et al., 2008). Of course, a necessary prerequisite would be to know oneself well enough in the first place. If leaders know their strengths, weakness, and values, and use that knowledge to guide their interactions with others, they are authentic leaders (Avolio and Gardner, 2005). Authentic leadership has four dimensions:

1) Self-awareness - deep knowledge of one's skills, values, and preferences.

2) Relational transparency - openness and integrity in interactions.

3) Balanced processing - consideration of diverse perspectives in decision making.

4) Internalized moral perspective - the demonstration of integrity and using one's values and well-evaluated external standards to guide behavior (Walumbwa et al., 2008; Cottrillet al., 2014).

\section{Organizational Justice}

James (1993) Defined organizational justice as the perception of individuals and groups regarding the fairness of the treatments they receive from organizations about their actions. Organizational justice is deeply rooted in Equity theory. According to Adam (1965), people are always comparing what they receive about what they do. They compare this ratio in their current situation with their previous situations andwith others. There are three 
dimensions of justice: distributional, procedural and interactional. Distributive justice is essentially about the equity theory - whether benefits are distributed fairly or not, regarding their "inputs" and "outputs" (Folger and Cropanzano, 1998). Procedural justice relates to the methods and mechanisms used to arrive at decisions. It is about the process. Distributive justice is about the "what" whereas procedural justice is about the "how". If the system is unfair (procedural) then the result or outcome (distributive) is also unfair. Lastly, interactional justice is about the communication involved. Were subordinates consulted? How was the result disseminated?

\section{Organizational Citizenship Behaviour (OCB) and the relationship with authentic leadership and justice perceptions}

According to Bateman and Organ (1983), OCB includes behaviors such as helping another colleague to solve jobrelated problems, accepting orders without any objections, carrying out tasks which are not their responsibility without complaints, and not overly critical. OCB is doing tasks which are not stated expressly in the job description. OCB has received a great deal of attention among researchers (Bateman \& Organ, 1983). OCB is related to job satisfaction, commitment, motivation, and leadership behavior (Bateman \& Organ, 1983; Organ, 1983; Organ \& Ryan, 1995; Organ \& Motowidlo, 1993). In particular, AlZaabi, Ahmad \& Hossan (2016) found that Authentic Leadership is significantly related to OCB among employees in the Oil Industry in the UAE.Accordingly the hypothesis is:

\section{H1: Authentic leadership is related to $\mathrm{OCB}$}

Regarding organizational justice, Williams et. Al (2002) observed that when supervisors treat employees fairly, more OCB is observed. Thus Organizational justice is also significantly related to OCB and the hypothesis is:

\section{H2: Organizational Justice is related to $\mathrm{OCB}$}

\section{Business Moral Value/ Ethical Value and its moderating effect}

Scott (2002, pg. 510) defined moral values as "beliefs about what is good and evil behavior within the individual's control, bearing on relations to self, to others, to God, and to the natural and animal world." Business moral values are the values that individuals hold when they engage in business activities (Carroll, 1987; Gandz and Hayes, 1988; Lewis, 1985). Personal moral values refer to the standard that employees or individuals see from their point of view whether the behavior is moral or notwhile interacting with others (Jiang,Lin \& Lin, 2011). Scott (2000), gave four principles of moral values: honest communication; (b) using one's own rights properly and not interfering with the rights of others; (c) respecting life; and (d) following rules and principles of justice. Schwartz's (2005) moral values has six dimensions: trustworthiness, respect, responsibility, fairness, caring and citizenship. Business moral values are guidance for employees to distinguish between the right and wrong behaviors (Carrol, 1987).

Fritzche and Becker (1984) mentioned that moral issues in organizational management include: supervisory coercion and control, conflicts of interest between organizations and employees, stress of the physical environment, balance between the interests of employees and those of customers, and personal integrity. The person-environment fit theory(Kristof, 1996) posits that when a person is congruent with the environment or situation, positive work outcomes such as high job satisfaction and OCB occurs. So it is proposed here that a highly moral employee, who works in an organization where HR practices are just, and matched with a leader who practices authentic leadership, that employee will be highly satisfied. Accordingly the hypothesis is:

2523-6547 - Copyright: (C) 2017 The Authors. This is an open access article distributed under the terms of the Creative Commons Attribution License, which permits unrestricted use, distribution, and reproduction in any medium, provided the original author and source are credited. 


\section{Conceptual Framework}

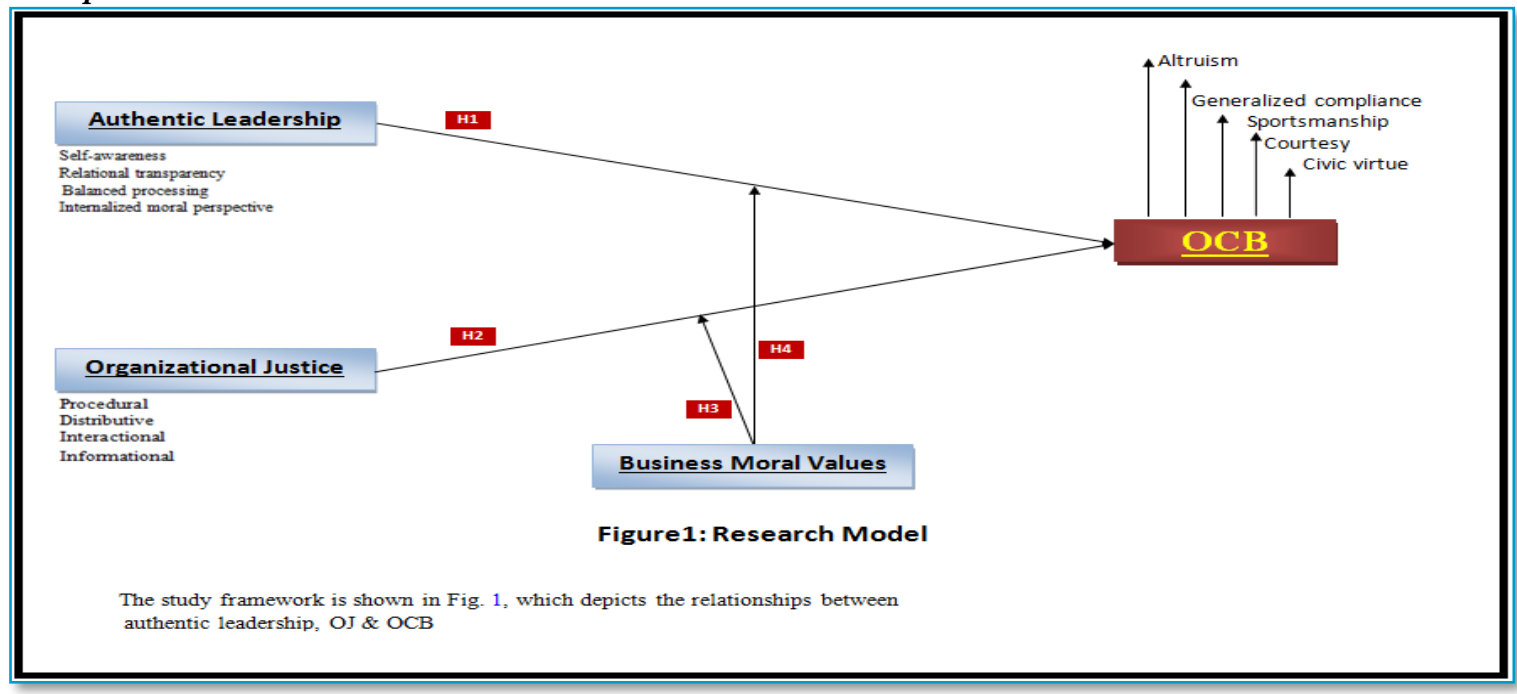

\section{CONCLUSION}

This research contributes to theory in that there is no known published research that investigated the moderating effects of moral values on the relationship between authentic leader and $\mathrm{OCB}$, and between organizational justice and OCB. The multidimensional perspectives of authentic leadership, organizational justice as well as OCB will be adopted, thus giving many combinations to be examined separately to determine which has the strongest effect. 


\section{REFERENCES}

1. Adams, S. J. (1965). Inequality in Social Exchange. In L. Berkowitz (Ed.). New York, NY: Academic Press, 267-299.

2. AlZaabi M.S.A., Ahmad, K.Z., \&Hossan, C. (2016). Authentic leadership, work engagement and organizational citizenship behaviors in petroleum company, International Journal of Productivity and Performance Management. 65(6), 811-830.

3. Avolio, B.J. \& Garder, W.L. (2005). Authentic leadership development: Getting to the root of positive forms of leadership.The Leadership Quarterly, 16(3), 315-338.

4. Bateman, T. S., \& Organ, D. W. (1983). Job satisfaction and the good soldier: The relationship between affect and employee "citizenship." Academy of Management Journal, 26(4), 587-

5.Blau, P. M. (1964). Social exchange theory.

6.Carroll, A. B. (1987). Linking Business Ethics to Behavior in Organization.Advanced Management Journal,43(3), 4-11.

7. Cottrill, K., Denise Lopez, P. \& Hoffman, C.(2014). How authentic leadership and inclusion benefit organizations. Equality Diversity and Inclusion.An International Journal33,(3), 275-292

8. Folger, R., \& Cropanzano, R. (1998). Organizational justice and human resource management. Thousand Oaks, CA: SAGE.

9. Fritzsche, D. J., \& Becker, H. (1984). Linking management behavior to ethical philosophy—An empirical investigation. Academy of Management journal, 27(1), 166-175.

10. Gandz, J.,\& N. Hayes (1988). Teaching Business Ethics, Journal of Business Ethics 7, 657-669.

11.Gardner, W. L., Avolio, B. J., Luthans, F., May, D. R., Walumbwa F. (2005). "Can you see the real me?" A self-based model of authentic leader and follower development, The leadership Quarterly, 16(3), 343 - 372

12.Gardner, W. L., Cogliser, C. C., Davis, K. M., \& Dickens, M. P. (2011). Authentic leadership: A review of the literature and research agenda. The Leadership Quarterly, 22(6), 1120-1145.

13. Homans, G. C. (1958). Social behavior as exchange. American Journal of Sociology, 63(6), 597-606.

14. Kristof, A. (1996). Person-organisation fit: an integrative review of it's conceptualisations, measurement, and implications. Personnel Psychology, 49, 1-49.

15. James, K. (1993). The social context of organizational justice: Cultural, intergroup, and structural effects on justice behaviors and perceptions. Justice in the workplace: Approaching fairness in human resource management, 21-50.

16. Jiang, D. Y., Lin, Lin, Y. C. \& Lin, L.C. (2011). Business Moral Values of Supervisors and Subordinates and their effect on Employee effectiveness. Journal of Business Ethics, 100, 239-252.

17. Lewis, P. V. (1985). Defining Business Ethics: Like Nailing Jelly to a Wall.Journal of Business Ethic4(5), 377-383.

18. Luthans, F. \& Avolio, B.J. (2003).“Authentic leadership development." Positive Organizational Scholarship: Foundations of a new Discipline., Berrett-Koehler, San Francisco

2523-6547 - Copyright: (C) 2017 The Authors. This is an open access article distributed under the terms of the Creative Commons Attribution License, which permits unrestricted use, distribution, and reproduction in any medium, provided the original author and source are credited. 
19. Organ, D.W. (1988), Organizational Citizenship Behavior: The God Soldier Syndrome, Lexington, MA: Lexington Books.

20. Organ, D. W., \& Ryan, K. (1995).A meta-analytic review of attitudinal and dispositional predictors of organizational citizenship behavior. Personnel Psychology, 48(4), 775-802. 42.

21. Organ, W. C., \& Motowidlo, S. J. (1993). Expanding the criterion domain to include elements of contextual performance.In N. Schmitt, W. C. Borman, \& Associates (Eds.), Personnel selection in organizations (pp. 7198). San-Francisco

22. Schwartz, M. S. (2005). Universal Moral Values for Corporate Codes of Ethics.Journal of Business Ethics, 59, 27-44.

23. Scott, E. D. (2000). Moral Values: Situationally Defined Individual Differences, Business Ethics Quarterly10(2), 497-521.

24. Scott, E.D. (2002). Organizational moral values. Business Ethics Quarterly, 12(1), 33.

25. Ugochukwu, O. (2016). The effect of organisational justice and organisational citizenship behaviours among private universities in Enugu state, Nigeria.International Journal of Information, Business and Management, 8(1)

26. Vision(2021) (n.d.) UAE Vision 2021 was launched by H.H. Sheikh Mohammed bin Rashid Al Maktoum, Vice-President and Prime Minister of the UAE and Ruler of Dubai, at the closing of a Cabinet meeting in 2010. Retrieved from http://www.vision2021.ae/en/national-priority-areas/safe-public-and-fair-judiciar

27. Walumbwa, F. O., Avolio, B. J., Gardner, W. L., Wernsing, T. S. \& Peterson, S. J. (2008). Authentic Leadership: Development and Validation of a Theory-Based Measure.Journal of Management,34(1), 89. 
2523-6547 - Copyright: (C) 2017 The Authors. This is an open access article distributed under the terms of the Creative Commons Attribution License, which permits unrestricted use, distribution, and reproduction in any medium, provided the original author and source are credited. 